\title{
Review of community pharmacy services: what is being performed, and where are the opportunities for improvement?
}

\section{Brittany L Melton \\ Zoe Lai}

Department of Pharmacy Practice, University of Kansas, Lawrence, $\mathrm{KS}$, USA
Correspondence: Brittany L Melton Department of Pharmacy Practice, University of Kansas Medical Center, Mailstop 4047, Lawrence, KS, USA Tel + I 9135885392

Email bmelton2@kumc.edu
This article was published in the following Dove Press journal:

Integrated Pharmacy Research and Practice

6 March 2017

Number of times this article has been viewed

Objective: The aim of this review was to assess pharmacist and pharmacy services being provided and identify opportunities to improve patient satisfaction.

Methods : Studies published between January 2006 and July 2016 examining patient satisfaction with pharmacy and pharmacist services, which were written in English, were identified in PubMed. Studies were excluded if they only looked at pharmacy student-provided services. Key findings: A total of 50 studies were ultimately included in the review. Of these studies, 28 examined services traditionally provided by community pharmacists such as dispensing and counseling, while 16 examined a new in-person service being offered by a pharmacy, and the remaining six involved a new technology-assisted service. While study findings were generally positive for patient satisfaction of pharmacy services, several opportunities were identified for pharmacies to improve. Conclusion: Overall, patient satisfaction is high across pharmacy services; however, this satisfaction is related to prior patient exposure to services and their level of expectation. Pharmacists have multiple opportunities to improve the services they provide, and there are additional services pharmacists may consider offering to expand their role within the health care system. Keywords: pharmacy, services, community, patient satisfaction

\section{Introduction}

In 2014, health care spending in the United States was three trillion dollars and represented $17.5 \%$ of the gross domestic product. ${ }^{1}$ There are nearly 300,000 pharmacists in the United States, and as the profession continues to evolve, the role that pharmacists play in the health care system is also evolving. ${ }^{2}$ Health care has shifted to a model of quality care for less cost, as a result of not only legislative action but also an increased emphasis on positive patient outcomes, while also dealing with an overall shortage of health care providers. ${ }^{3}$ This has provided community pharmacists, who were already highly accessible to patients, an opportunity to become more than medication dispensers. The impact pharmacists can have on patient care can be measured not only by clinical outcomes but also by patient satisfaction with the service. This review sought to analyze the available literature on community pharmacy services not only to identify and evaluate what pharmacies are currently doing well to provide patient satisfaction but also to identify opportunities to improve as a profession.

\section{Methods}

A systematic search of literature indexed in PubMed during the 10-year period between 2006 and 2016 was conducted to identify the most recent trends in pharmacy services 
and patient satisfaction. For the search, the terms "pharmacy services", "patient satisfaction", and "community" were used. The term "community" was used to capture both community pharmacies and clinics which may be part of a community pharmacy's services or in a stand-alone facility but are not clearly described. Results were limited to human studies and articles published in English. Articles were included if

1. The study included an intervention, assessment of current service, or comparison between services.

2. The study service was conducted by pharmacists.

3. The focus of the study was on community pharmacies or outpatient clinics.

4. The study examined a community pharmacy service, such as counseling, care management, and immunizations.

Articles were subsequently excluded for review if

1. The title, abstract, or full text of the article indicated that the article did not discuss an outpatient pharmacy service or only looked at student pharmacists.

2. The article was a case study, review, or meta-analysis.

3. The article only focused on inpatient care.

4. The study intervention was conducted by only pharmacy students.

5. The article discussed guidelines/methods/best practices for the design or implementation of a service without application.

6. The full text could not be obtained.

The process of identifying and reviewing articles is shown in Figure 1. Two levels of review were performed. The first was the literature search conducted using the search terms identified, and then all article titles and abstracts were reviewed. The initial search identified 259 articles, which was subsequently reduced to 104 after reviewing the titles and abstracts. The second review involved evaluating the remaining full articles to identify content that met the inclusion criteria. Another 54 articles were excluded because of the focus of the article or the full text not being available. Ultimately, 50 articles were included for review.

These articles were subsequently classified by the type of service being provided and the scope of practice for that service to more easily assess patient satisfaction with services and how pharmacists may improve the provision of services. For the purposes of this review, the term "pharmacy service" refers only to services provided in the community or outpatient setting. Services were classified as a standard pharmacist activity (Table 1), such as medication counseling and dispensing; a new in-person service (Table 2 ), such as providing vaccinations

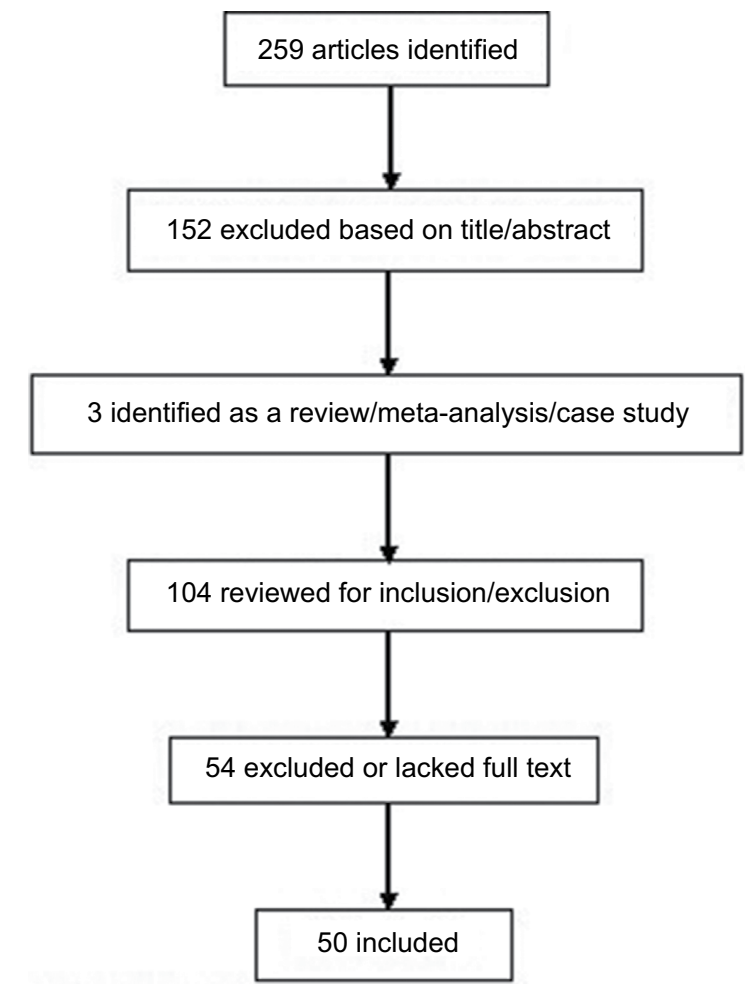

Figure I Inclusion/exclusion criteria.

or mental health screenings; or a new technology-assisted service (Table 3 ), such as electronic medication management and distance counseling. Activities were further classified into four groups; 1) standard practice, which means anything pharmacists were traditionally able to perform; 2) a service that required training specifically for the study but fell within what pharmacists were legally able to do; 3) an expanded practice, which means anything that pharmacists have recently been allowed to do, such as vaccinations; and 4) activities that required a collaborative practice agreement to perform.

\section{Types of services}

The majority (56\%) of studies identified for review inclusion examined a pharmacy service that was defined as a standard practice. Only six of these studies were completed in the United States, while the remainder were completed in countries with some type of national health care, such as Australia, the United Kingdom, and Canada. As a trusted and accessible health care professional, the community pharmacist is often the first point of contact for patients, particularly for over-the-counter (OTC) products, and patients are generally satisfied with the pharmacist's interaction. ${ }^{4}$ Patients also rely on pharmacists for medicine information when they cannot get all the information they need from their physicians, which allows pharmacists to have an impact on adherence. ${ }^{5}$ 
Table I Studies involving standard pharmacist's activities included in the review

\begin{tabular}{|c|c|c|c|}
\hline Reference & Country & Study focus & Results \\
\hline $\begin{array}{l}\text { Watson et a }{ }^{49} \\
\text { Study type: observational } \\
\text { Scope of practice: standard practice }\end{array}$ & Scotland & $\begin{array}{l}\text { Compare health- and cost-related outcomes } \\
\text { of consultations for minor ailments } \\
\text { symptoms }\end{array}$ & $\begin{array}{l}\text { Convenience of location was the most } \\
\text { common reason for choice of consultation } \\
\text { setting }\end{array}$ \\
\hline $\begin{array}{l}\text { Akol et a }{ }^{12} \\
\text { Study type: interview } \\
\text { Scope of practice: training specifically } \\
\text { for study }\end{array}$ & Uganda & $\begin{array}{l}\text { Assess perspectives on the quality of } \\
\text { care and satisfaction with intramuscular } \\
\text { administration of contraception by drug } \\
\text { store owners }\end{array}$ & $\begin{array}{l}\text { Most were satisfied receiving their } \\
\text { contraception from the drug shop and } \\
\text { intended to get the next injection from the } \\
\text { drug shop }\end{array}$ \\
\hline $\begin{array}{l}\text { Patricia et al }{ }^{8} \\
\text { Study type: descriptive } \\
\text { Scope of practice: standard practice }\end{array}$ & Portugal & $\begin{array}{l}\text { Identify factors that contribute to patients' } \\
\text { pharmacy loyalty }\end{array}$ & $\begin{array}{l}\text { Humanistic-based skills were found to } \\
\text { promote customers' visit to pharmacies }\end{array}$ \\
\hline $\begin{array}{l}\text { Malewski et al } \\
\text { Study type: survey } \\
\text { Scope of practice: standard practice }\end{array}$ & USA & $\begin{array}{l}\text { Examine urban and suburban community } \\
\text { pharmacy populations for similarities and } \\
\text { differences in patient satisfaction }\end{array}$ & $\begin{array}{l}\text { Satisfaction with pharmacist's relationship an } \\
\text { service high with no significant differences } \\
\text { between locations }\end{array}$ \\
\hline $\begin{array}{l}\text { Mansell et a }{ }^{25} \\
\text { Study type: evaluation } \\
\text { Scope of practice: standard practice }\end{array}$ & Canada & $\begin{array}{l}\text { Assess symptomatic improvement for } \\
\text { patients treated by a pharmacist }\end{array}$ & $\begin{array}{l}\text { Patients were very satisfied with their } \\
\text { symptomatic improvement and with the } \\
\text { service in general }\end{array}$ \\
\hline $\begin{array}{l}\text { Kjeldsen et } \mathrm{al}^{21} \\
\text { Study type: randomized control trial }\end{array}$ & Denmark & $\begin{array}{l}\text { Investigate if a brief, comprehensive } \\
\text { individually targeted intervention for }\end{array}$ & $\begin{array}{l}\text { The study showed improvement in patient } \\
\text { health, well-being, knowledge, and satisfactic }\end{array}$ \\
\hline
\end{tabular}

Scope of practice: training specifically for study

McMillan et al ${ }^{10}$

diabetic patients could improve drug therapy implementation in pharmacies

Study type: semi-structured interviews

Scope of practice: standard practice

Tan et al ${ }^{20}$

Study type: pre/post-intervention

Scope of practice: standard practice

Patterson et $\mathrm{al}^{7}$

Australia Explore the attributes of pharmacy choice for people with chronic conditions

Australia Evaluate the effectiveness of pharmacist's consultations based on primary care practices

Study type: cross-sectional study Scope of practice: standard practice

Jaffray et al ${ }^{52}$

Identify relationships among pharmacy service use, general and service-specific patient satisfaction, pharmacy patronage motives, and marketing awareness

Study type: randomized control trial

Scope of practice: training specifically for study

Tran et al ${ }^{14}$

Study type: interviews

Scope of practice: standard practice

Rubio-Valera et a ${ }^{23}$

Study type: randomized control trial

Scope of practice: training specifically

for study

Kaae et al $^{16}$

Study type: semi-structured interviews

Scope of practice: standard practice

Collum et al ${ }^{13}$

Study type: pilot study

Scope of practice: standard practice

Bosse et $\mathrm{a}^{24}$

Scotland

Determine whether trained pharmacists can improve methadone outcomes

Australia Explore pharmacist-consumer interactions about complementary medicines, with focus on consumer expectations, perceptions, and satisfaction

Spain Evaluate the impact of a pharmacist's intervention on patients who had initiated antidepressant treatment

Denmark Investigate how patients perceive pharmacy counseling at the present time, to develop the patient-pharmacy relationship

Describe the satisfaction of patients at high risk for medication misadventures with care communication at a clinic-based pharmacy

USA Evaluate if patient adherence to selfcare advice from a pharmacist provides satisfactory symptom relief

Scope of practice: standard practice van Geffen et al ${ }^{17}$

Study type: survey

Scope of practice: standard practice

The Assess patient perceptions of received

Netherlands cardiovascular drug information and counseling
Five attributes influenced this choice: patientcentered care, convenience, price, personal traits, and service/medication need Patients were highly satisfied with the pharmacist's consultations and were effective in identifying and resolving medication-related problems

Study participants were mostly satisfied with the pharmacy services on global and servicespecific measures

It did not significantly reduce heroin use, but there are indications of increased communication and satisfaction

There was high consumer satisfaction, which was in agreement with pharmacist's perceptions of consumer satisfaction

Patients showed improvement in healthrelated quality of life, but none in clinical symptoms or pharmacy satisfaction

Customers favor pharmacy OTC medication counseling and first-time prescriptions, but find it hard to express the role of pharmacies

Few patients reported the use of recommended communication techniques by the pharmacist

Patients felt that it led to greater symptom improvement, and would like to see this service offered all of the time

Most were unsatisfied with the information received and reported not experiencing some counseling activities 
Table I (Continued)

\begin{tabular}{|c|c|c|c|}
\hline Reference & Country & Study focus & Results \\
\hline $\begin{array}{l}\text { Naik Panvelkar et al }{ }^{15} \\
\text { Study type: interview } \\
\text { Scope of practice: standard practice }\end{array}$ & Australia & $\begin{array}{l}\text { Explore patient preferences for types of } \\
\text { pharmacy-based asthma services and identify } \\
\text { service aspects that patients prefer }\end{array}$ & $\begin{array}{l}\text { Both naive and experienced patients had a } \\
\text { high level of satisfaction }\end{array}$ \\
\hline $\begin{array}{l}\text { Black et al }{ }^{19} \\
\text { Study type: survey } \\
\text { Scope of practice: standard practice }\end{array}$ & Canada & $\begin{array}{l}\text { Determine patient preferences, satisfaction, } \\
\text { and perceived stigma related to pharmacists }\end{array}$ & $\begin{array}{l}\text { Traditional pharmacy services were perceived } \\
\text { to be of greater importance than some clinical } \\
\text { services }\end{array}$ \\
\hline $\begin{array}{l}\text { Simoens et } \text { al }^{4} \\
\text { Study type: survey } \\
\text { Scope of practice: standard practice }\end{array}$ & Belgium & $\begin{array}{l}\text { Explore patient experiences of purchasing } \\
\text { OTC medications in pharmacies }\end{array}$ & $\begin{array}{l}\text { Patients were satisfied with pharmacy } \\
\text { distribution and services related to OTC } \\
\text { medications }\end{array}$ \\
\hline $\begin{array}{l}\text { van Geffen et al } \\
\text { Study type: descriptive } \\
\text { Scope of practice: standard practice }\end{array}$ & $\begin{array}{l}\text { The } \\
\text { Netherlands }\end{array}$ & $\begin{array}{l}\text { Examine patients' perceptions of } \\
\text { information received when starting a } \\
\text { selective serotonin reuptake inhibitor, to } \\
\text { identify needs and the potential role of the } \\
\text { pharmacist }\end{array}$ & $\begin{array}{l}\text { Patients felt that they would benefit from } \\
\text { tailored information. Many patients required } \\
\text { more concrete and practical information than } \\
\text { was provided }\end{array}$ \\
\hline $\begin{array}{l}\text { Hoffmann et } \mathrm{al}^{22} \\
\text { Study type: randomized controlled trial } \\
\text { Scope of practice: training specifically } \\
\text { for study }\end{array}$ & Germany & $\begin{array}{l}\text { Evaluate the effects of pharmaceutical care } \\
\text { for patients with headache or migraine, on } \\
\text { both clinical and psychological end points }\end{array}$ & $\begin{array}{l}\text { Most participants described this intervention } \\
\text { as helpful and effective and reported that they } \\
\text { would recommend pharmaceutical care to } \\
\text { others }\end{array}$ \\
\hline $\begin{array}{l}\text { McAuley et al" } \\
\text { Study type: survey } \\
\text { Scope of practice: standard practice }\end{array}$ & USA & $\begin{array}{l}\text { Survey patients with epilepsy about the } \\
\text { current and potential role pharmacists play/ } \\
\text { could play in their care }\end{array}$ & $\begin{array}{l}\text { Patients reported good relationships with } \\
\text { their pharmacists, but were concerned about } \\
\text { lack of privacy and did not want to pay for } \\
\text { services }\end{array}$ \\
\hline $\begin{array}{l}\text { Du Pasquier and } \text { Aslani }^{5} \\
\text { Study type: semi-structured interview } \\
\text { Scope of practice: standard practice }\end{array}$ & Australia & $\begin{array}{l}\text { Explore consumers' attitudes toward, and } \\
\text { expectations of, adherence support services } \\
\text { in a pharmacy }\end{array}$ & $\begin{array}{l}\text { Participants valued two-way communication } \\
\text { and increased consideration of their needs/ } \\
\text { beliefs, but were hesitant about shared } \\
\text { decision making }\end{array}$ \\
\hline
\end{tabular}

Abbreviation: OTC, over the counter.

Table 2 Studies involving new in-person services included in the review

\begin{tabular}{|c|c|c|c|}
\hline Reference & Country & Study focus & Results \\
\hline $\begin{array}{l}\text { Luder et a }{ }^{42} \\
\text { Study type: prospective, quasi- } \\
\text { experimental } \\
\text { Scope of practice: training specifically } \\
\text { for study }\end{array}$ & USA & $\begin{array}{l}\text { If transition of care has decreased hospital } \\
\text { readmission, resolved medication problems, } \\
\text { and increased patient satisfaction }\end{array}$ & $\begin{array}{l}\text { A community pharmacist in the usual discharge } \\
\text { process improved the quality of care and } \\
\text { significantly reduced hospital readmissions }\end{array}$ \\
\hline $\begin{array}{l}\text { O'Neal et al }{ }^{34} \\
\text { Study type: observational } \\
\text { Scope of practice: training specifically } \\
\text { for study }\end{array}$ & USA & $\begin{array}{l}\text { Develop and assess a tool evaluating the } \\
\text { impact of a pharmacist's training program } \\
\text { from the patients' perspective }\end{array}$ & $\begin{array}{l}\text { A continuing education program is desired and } \\
\text { has the potential to impact the quality of life for } \\
\text { migraine and recurrent headache sufferers }\end{array}$ \\
\hline $\begin{array}{l}\text { Hanes et } \mathrm{a}^{35} \\
\text { Study type: survey } \\
\text { Scope of practice: expanded practice }\end{array}$ & Australia & $\begin{array}{l}\text { Perspectives of pharmacy staff involved in } \\
\text { CPAP and sleep apnea-related services }\end{array}$ & $\begin{array}{l}\text { Respondents felt there was room for } \\
\text { improvement in some aspect of CPAP service }\end{array}$ \\
\hline $\begin{array}{l}\text { Jackson et al }{ }^{40} \\
\text { Study type: survey } \\
\text { Scope of practice: collaborative } \\
\text { practice agreement }\end{array}$ & USA & $\begin{array}{l}\text { Enhance public access to prophylaxis for } \\
\text { Lyme disease and assess patient satisfaction } \\
\text { with the pharmacy-based service provided }\end{array}$ & $\begin{array}{l}\text { High level of satisfaction with pharmacy services } \\
\text { provided, and no reports of subsequent } \\
\text { development of symptoms or major adverse } \\
\text { events }\end{array}$ \\
\hline $\begin{array}{l}\text { Rickles et al }{ }^{38} \\
\text { Study type: evaluation } \\
\text { Scope of practice: training specifically } \\
\text { for study }\end{array}$ & USA & $\begin{array}{l}\text { Evaluate the impact and patient satisfaction } \\
\text { of a pharmacy-based cognitive memory } \\
\text { screening and referral program }\end{array}$ & $\begin{array}{l}\text { Cognitive memory screening can be easily } \\
\text { incorporated into clinical service offerings in a } \\
\text { pharmacy }\end{array}$ \\
\hline $\begin{array}{l}\text { Breslow }^{39} \\
\text { Study type: observational } \\
\text { Scope of practice: training specifically } \\
\text { for study }\end{array}$ & USA & $\begin{array}{l}\text { Describe patient attitudes and satisfaction } \\
\text { toward pharmacist-administered memory } \\
\text { screenings }\end{array}$ & $\begin{array}{l}\text { The majority of participants responded } \\
\text { favorably to several aspects of offering memory } \\
\text { screening in pharmacies }\end{array}$ \\
\hline
\end{tabular}


Table 2 (Continued)

\begin{tabular}{|c|c|c|c|}
\hline Reference & Country & Study focus & Results \\
\hline $\begin{array}{l}\text { Hui-Callahan et } \mathrm{al}^{28} \\
\text { Study type: prospective } \\
\text { Scope of practice: training specifically } \\
\text { for study }\end{array}$ & USA & $\begin{array}{l}\text { Determine if diabetic patients who used } \\
\text { a financial rewards program in a grocery } \\
\text { chain pharmacy had increased rates of self- } \\
\text { reported healthy behaviors }\end{array}$ & $\begin{array}{l}\text { Satisfaction was favorable. Participants reported } \\
\text { that the program increased behavior awareness } \\
\text { and accountability, and motivation to improve } \\
\text { health }\end{array}$ \\
\hline $\begin{array}{l}\text { DiDonato et } \mathrm{a}^{37} \\
\text { Study type: prospective cohort } \\
\text { Scope of practice: standard practice }\end{array}$ & USA & $\begin{array}{l}\text { Assess the clinical and patient-centered } \\
\text { outcomes of pharmacist's health coaching in } \\
\text { the workplace }\end{array}$ & $\begin{array}{l}\text { Wellness coaching by a pharmacist can result in } \\
\text { significant improvements in cardiovascular risk } \\
\text { factors }\end{array}$ \\
\hline $\begin{array}{l}\text { Warner et } \mathrm{a}^{33} \\
\text { Study type: observational } \\
\text { Scope of practice: expanded practice }\end{array}$ & England & $\begin{array}{l}\text { Determine if the inclusion of pharmacies } \\
\text { improve vaccination rates and is acceptable } \\
\text { to patients }\end{array}$ & $\begin{array}{l}\text { Pharmacies can help increase vaccination rates } \\
\text { and has high levels of patient acceptability }\end{array}$ \\
\hline $\begin{array}{l}\text { American Pharmacists Association }{ }^{29} \\
\text { Study type: observational } \\
\text { Scope of practice: training specifically } \\
\text { for study }\end{array}$ & USA & $\begin{array}{l}\text { Describe the development and } \\
\text { implementation of the Discussions on } \\
\text { Taking Medications Diabetes Pilot Program } \\
\text { and satisfaction }\end{array}$ & $\begin{array}{l}\text { Small, focused interactions addressing issues } \\
\text { of concern to patients could improve patient } \\
\text { adherence to medication therapy }\end{array}$ \\
\hline $\begin{array}{l}\text { Shoukry et al }{ }^{36} \\
\text { Study type: qualitative } \\
\text { Scope of practice: standard practice }\end{array}$ & Australia & $\begin{array}{l}\text { Explore the experiences of patients with } \\
\text { obstructive sleep apnea who get treatment } \\
\text { through pharmacies }\end{array}$ & $\begin{array}{l}\text { High satisfaction with pharmacy services was } \\
\text { expressed, with convenience and good service } \\
\text { as notable characteristics }\end{array}$ \\
\hline $\begin{array}{l}\text { Saini et a }{ }^{30} \\
\text { Study type: pre/post-intervention } \\
\text { Scope of practice: training specifically } \\
\text { for study }\end{array}$ & Australia & $\begin{array}{l}\text { Assess any improvements in knowledge of } \\
\text { asthma patients after a tailored education } \\
\text { program delivered by pharmacists and } \\
\text { sustainability of improvements }\end{array}$ & $\begin{array}{l}\text { Asthma knowledge significantly improved as a } \\
\text { result of the service, and patients changed the } \\
\text { way they managed their asthma }\end{array}$ \\
\hline $\begin{array}{l}\text { Mitchell et } \mathrm{al}^{27} \\
\text { Study type: longitudinal } \\
\text { Scope of practice: training specifically } \\
\text { for study }\end{array}$ & Australia & $\begin{array}{l}\text { Evaluate the capacity and effectiveness } \\
\text { of trained pharmacists in delivering the } \\
\text { Diabetes Medication Assistance Service }\end{array}$ & $\begin{array}{l}\text { Patients reported improvements in knowledge } \\
\text { about diabetes self-management, and improved } \\
\text { glycemic control and adherence }\end{array}$ \\
\hline $\begin{array}{l}\text { Hugtenburg et } \mathrm{al}^{41} \\
\text { Study type: controlled intervention } \\
\text { Scope of practice: standard practice }\end{array}$ & $\begin{array}{l}\text { The } \\
\text { Netherlands }\end{array}$ & $\begin{array}{l}\text { Evaluate a comprehensive protocol for } \\
\text { discharge care on patient satisfaction as well } \\
\text { as on drug use compliance and mortality }\end{array}$ & $\begin{array}{l}\text { Patient counseling at discharge from hospital by } \\
\text { pharmacists appears to be meaningful }\end{array}$ \\
\hline $\begin{array}{l}\text { Lea et a }{ }^{32} \\
\text { Study type: survey } \\
\text { Scope of practice: standard practice }\end{array}$ & Australia & $\begin{array}{l}\text { Explore consumer satisfaction associated } \\
\text { with the delivery of opioid substitution } \\
\text { treatment at pharmacies }\end{array}$ & $\begin{array}{l}\text { Participants expressed a high level of } \\
\text { satisfaction with most service aspects, but } \\
\text { wanted more privacy }\end{array}$ \\
\hline $\begin{array}{l}\text { Saini et al }{ }^{31} \\
\text { Study type: repeated measures } \\
\text { Scope of practice: training specifically } \\
\text { for study }\end{array}$ & Australia & $\begin{array}{l}\text { Compare the effect of a pharmacist- } \\
\text { delivered rural asthma management service } \\
\text { on health outcomes for people with asthma }\end{array}$ & $\begin{array}{l}\text { Patients had a reduction in the asthma severity } \\
\text { and risk of nonadherence to medication scores, } \\
\text { and an increase in patients with a written action } \\
\text { plan }\end{array}$ \\
\hline
\end{tabular}

Abbreviation: CPAP, continuous positive airway pressure.

Patient satisfaction is generally high when patients are loyal to pharmacies where they have a good relationship with the staff and appreciate the overall atmosphere of the pharmacy. ${ }^{6,7}$ Patients also reported greater pharmacy loyalty when the pharmacist had more relational skills rather than just technical knowledge. ${ }^{8}$ Patient loyalty and satisfaction was found even for patients who get prescriptions filled at a pharmacy that only offered standard brief medication counseling rather than advanced services, such as medication therapy management. ${ }^{9}$ Similar results were found when interviewing patients with chronic diseases specifically, and patients feel pharmacists do a good job addressing concerns related to epilepsy medications. ${ }^{10,11}$ Pharmacists in Uganda providing intramuscular contraception were preferred over government providers due to reduced wait times, convenience, and respect they received from the pharmacists, and this reflects other studies that found similar reasons for a positive patient perception of the pharmacy experience, and subsequent patient satisfaction with the services. ${ }^{12}$ While interpersonal interactions are a predictor of patient satisfaction with the pharmacy experience, patients also report that pharmacist's counseling yields a good understanding of their medications, which may, in turn, improve satisfaction. ${ }^{13}$ Despite patients reporting they are satisfied with the information regarding complementary medicine, they also report low expectations of the pharmacist's knowledge on complementary medicine. ${ }^{14}$ As patients experience a service, however, their expectations for the service increase, and the pharmacist may need to do more to produce patient satisfaction, as was seen when patients were interviewed about an asthma service and may be seen for other services as patients begin to recognize their knowledge limitations and what they need in a particular 
Table 3 Studies involving new technology-assisted services included in the review

\begin{tabular}{|c|c|c|c|}
\hline Reference & Country & Study focus & Results \\
\hline $\begin{array}{l}\text { Butler et al } \\
\text { Study type: survey } \\
\text { Scope of practice: standard } \\
\text { practice }\end{array}$ & USA & $\begin{array}{l}\text { Patient satisfaction with medication } \\
\text { synchronization }\end{array}$ & $\begin{array}{l}\text { All patients were highly satisfied with medication } \\
\text { synchronization program, and it should expand to a } \\
\text { wider population }\end{array}$ \\
\hline $\begin{array}{l}\text { Shaw et al }{ }^{48} \\
\text { Study type: observational } \\
\text { Scope of practice: training } \\
\text { specifically for study }\end{array}$ & $\begin{array}{l}\text { New } \\
\text { Zealand }\end{array}$ & $\begin{array}{l}\text { Examine attitudes toward a new collaborative } \\
\text { pharmacy-based model of care for the } \\
\text { management of warfarin treatment }\end{array}$ & $\begin{array}{l}\text { The model of care was highly valued by patients and } \\
\text { supported by primary care practitioners }\end{array}$ \\
\hline $\begin{array}{l}\text { Stuurman-Bieze et } \mathrm{al}^{45} \\
\text { Study type: pre/post- } \\
\text { intervention } \\
\text { Scope of practice: training } \\
\text { specifically for study }\end{array}$ & $\begin{array}{l}\text { The } \\
\text { Netherlands }\end{array}$ & $\begin{array}{l}\text { Determine the effects of a pharmacists' } \\
\text { intervention on the I-year discontinuation and } \\
\text { adherence rates of osteoporosis medication }\end{array}$ & $\begin{array}{l}\text { Program significantly decreased the number of } \\
\text { patients discontinuing osteoporosis medication }\end{array}$ \\
\hline $\begin{array}{l}\text { Stuurman-Bieze et } \text { al }^{46} \\
\text { Study type: prospective } \\
\text { intervention } \\
\text { Scope of practice: training } \\
\text { specifically for study }\end{array}$ & $\begin{array}{l}\text { The } \\
\text { Netherlands }\end{array}$ & $\begin{array}{l}\text { Assess the effect of a proactive care } \\
\text { intervention program and patients' satisfaction }\end{array}$ & $\begin{array}{l}\text { Patient satisfaction was very high. Pharmacists can } \\
\text { contribute to optimal use of chronic medications }\end{array}$ \\
\hline $\begin{array}{l}\text { Billups et } \text { al }^{44} \\
\text { Study type: quasi-experimental } \\
\text { Scope of practice: training } \\
\text { specifically for study }\end{array}$ & USA & $\begin{array}{l}\text { Compare completeness of medication and } \\
\text { blood pressure monitoring for patients } \\
\text { requesting medication refills through multiple } \\
\text { services }\end{array}$ & $\begin{array}{l}\text { Pharmacists managing chronic medications resulted } \\
\text { in more complete medication monitoring compared } \\
\text { to others }\end{array}$ \\
\hline $\begin{array}{l}\text { Beaucage et } \text { al }^{47} \\
\text { Study type: randomized } \\
\text { controlled trial } \\
\text { Scope of practice: standard } \\
\text { practice }\end{array}$ & Canada & $\begin{array}{l}\text { Study the impact of a pharmacist's telephone } \\
\text { follow-up intervention on clinical outcomes, } \\
\text { pharmaceutical care, and costs for patients } \\
\text { undergoing antibiotic treatment }\end{array}$ & $\begin{array}{l}\text { A telephone follow-up is simple and quick, but it did } \\
\text { not improve the number of infectious symptoms or } \\
\text { the infection severity score }\end{array}$ \\
\hline
\end{tabular}

service. ${ }^{15}$ Conversely, patients are more satisfied with medication counseling more for OTC products and first-time prescription fills rather than refills. ${ }^{16}$ Patients are not always satisfied with the information they receive, however. Patients surveyed about the education they received regarding their cardiovascular medications and selective serotonin reuptake inhibitors found that more than half were unsatisfied, and they felt they did not receive enough practical information. ${ }^{17,18}$ They also reported a lack of empathy to be a barrier to improved communication, and potentially a limitation on patient satisfaction, with the pharmacist. ${ }^{18}$ A similar survey of mental health patients found that patients believe medication education is a more important role for pharmacists than providing medication recommendations, and they perceived the main value of community pharmacists is in their availability, reinforcing that patient satisfaction may be tied to a pharmacist's accessibility. ${ }^{19}$

Patient satisfaction with the interaction and the knowledge provided by the pharmacist is important for pharmacy loyalty; however, satisfaction is not sufficient to produce positive health outcomes. Pharmacists are consistently able to identify medication-related problems and improve medication adherence, which can in turn improve patient outcomes. ${ }^{20}$
When patients received diabetes-focused medication counseling, those patients who received a more intensive intervention had greater improvement, indicating the importance of pharmacist's knowledge as a component of care. ${ }^{21}$ Similarly, German pharmacists who counseled patients specifically regarding their headaches produced an increase in mental health and self-efficacy over patients who received usual pharmacy counseling. ${ }^{22}$ When community pharmacists provided education to patients newly diagnosed with depression, patients reported a higher health-related quality of life but did not report a higher level of satisfaction compared to those who did not receive focused education, despite the improved quality of life. ${ }^{23}$ Interventions involving OTC products and minor ailments can also show symptom relief and in the case of pharmacist prescribing for minor ailments, high patient satisfaction as well. ${ }^{24,25}$ The same was also found for pharmacist's counseling on lifestyle modifications and disease prevention; however, one study found that such counseling is rarely provided in rural community pharmacies. ${ }^{26}$

Only $16(32 \%)$ of studies included in the review looked at a newly developed in-person service offered in a community pharmacy. Approximately half of those studies that looked at a new in-person service were related to medication 
management, three of which were specific to diabetes. Pharmacists were able to improve patient knowledge about diabetes self-management and made multiple interventions per patient to assist patients in reaching their goals while maintaining a high level of patient satisfaction with the service. ${ }^{27}$ Similarly, providing diabetic patients a financial incentive for maintaining behavior logs and receiving counseling from pharmacists regarding health behaviors had a high patient satisfaction and improved patient engagement in their care. ${ }^{28}$ The DOTx. MED study furthered the concept of involving pharmacists in diabetes management conversations by including the pharmacist in dialog between the physician and patient to improve adherence to improve patient control of diabetes and satisfaction with diabetes care. ${ }^{29}$ The other identified medication management-related studies focused on asthma. Two Australian studies examining patient-tailored interventions for asthma improved knowledge and led to a change in disease management, but unlike the diabetes services, the asthma study found that patient knowledge was maintained for at least a year after the intervention had ended, along with improved asthma outcomes and high patient satisfaction. ${ }^{30,31}$ Community pharmacies in Australia may also provide opioid substitution therapy, and patients were highly satisfied with the service they received at the pharmacy. ${ }^{32}$ Beyond medication and disease state management, pharmacies provide vaccinations, including influenza. A study on the Isle of Wight found that pharmacists provided nearly $10 \%$ of influenza vaccinations administered on the island, and the majority of patients approved of the convenience and speed of service associated with receiving vaccinations at a community pharmacy rather than a physician's office. ${ }^{33}$

Other new services provided by community pharmacies included various types of screening/wellness counseling. Education is an important component of community pharmacist's counseling and care, and some studies examined opportunities to expand education to topics not traditionally integrated in pharmaceutical care. One such study provided continuing education to pharmacists to provide care to those with migraines and recurrent headaches, which found overall there were positive patient perceptions of the pharmacists' care management, even with a limited sample size. ${ }^{34}$ Another two articles examined a program where pharmacists provided continuous positive airway pressure (CPAP) to patients suffering from obstructive sleep apnea. ${ }^{35,36}$ While there was a pharmacist's perception of providing a needed service to the community, patients reported that the information they received at diagnosis was not generally sufficient to meet their needs. ${ }^{35,36}$ Wellness coaching and counseling provided by community pharmacists can produce significant improvements in cholesterol, blood pressure, and blood glucose measurements with a continuously high level of patient satisfaction. ${ }^{37}$ Studies of cognitive screening services in community pharmacies have been well received by patients, as those the pharmacist identifies to be at risk could be referred to their physician for further follow-up earlier than they might otherwise be identified, and patients believed it was a good idea for pharmacies to offer memory screenings. ${ }^{38,39}$ Expanding pharmacist services further under a collaborative practice agreement allowed pharmacists to screen patients and dispense prophylactic doxycycline, which resulted in no patients developing Lyme disease and patients being highly satisfied with the pharmacist's interaction..$^{40}$ Pharmacist involvement in transitions of care is also occurring in community pharmacies as a way to improve care and reduce hospital readmissions, but the results have been mixed. One study found pharmacists providing medication reconciliation and counseling for polypharmacy patients upon hospital discharge as part of a multifaceted longitudinal intervention was found to reduce medication costs, but did not impact mortality, but patients who received medication counseling from community pharmacists were more satisfied with the counseling. ${ }^{41}$ However, another study of transition of care programs found a significant reduction in hospital readmissions by having pharmacists conduct medication reconciliation and patient education, but no difference in patient satisfaction between those who were seen by a pharmacist and those who were not. ${ }^{42}$

The remaining six studies (12\%) assessed a new technologyassisted pharmacy service. The application of technology to community pharmacy services was predominately limited to systems that facilitate standard pharmacy services, such as filling prescriptions, and as a means of monitoring/recording patient care information as part of a larger intervention. ${ }^{43-47}$ A program that synchronized medications and provided automated calls to patients allowed patients to make fewer trips to the pharmacy and had high patient satisfaction while it also allowed pharmacy staff to reduce workload, but the study was limited. ${ }^{43} \mathrm{~A}$ community pharmacy with access to a patient's electronic medical record was able to evaluate laboratory measures and order tests if needed, ultimately reducing the number of medication refills requested that lacked necessary monitoring and improved patient satisfaction related to prescriptions being ready in a timely manner. ${ }^{44}$ Similarly, two Dutch studies looked at adherence for various types of medications and utilized electronic health records to determine whether patients should be contacted about 
refilling their prescriptions, as part of a larger patient-centered intervention with patients being highly satisfied with the change and indicating that the pharmacy was the only place where they had received information related to medication effectiveness. ${ }^{45,46}$ Taking patient care a step further, one study found that use of a phone call to follow up on antibiotic use is effective in identifying drug-related problems, but it was not found to improve symptoms patients experienced or patient satisfaction. ${ }^{47}$ Another study examined the implementation of an anticoagulation service that incorporated clinical decision support in community pharmacies and found that patients preferred it for convenience and access, and physicians appreciated the time saved. ${ }^{48}$

\section{Opportunities for improvement}

While many studies noted patients were satisfied with the services they received from a community pharmacy, the results were not universal, and there are opportunities for pharmacies to improve upon offered services or expand into new areas. Access is often cited as a reason for receiving or preferring services at a community pharmacy, but that could lead to increased workload for pharmacies. ${ }^{33,48}$ While patients are generally happy with their pharmacists, there are differences in perceived access between urban and suburban areas, which pharmacists may be able to address through greater awareness of population differences. ${ }^{6}$

Services offered by a pharmacist often require additional pharmacist's time or resources, and that should be considered in developing a new service. Training pharmacists to provide repeated review and education on diabetes self-management can have a noticeable improvement in achieving patient goals, but it requires pharmacist's time and commitment. ${ }^{27}$ Focused interventions that involved motivational interviewing can increase not only patient adherence but also the time pharmacists need to spend with individual patients. ${ }^{29}$ However, there is an opportunity to potentially limit the intervention to a few visits over a period of several months and maintain lasting effects, but it has not been heavily explored. ${ }^{30}$

In addition to the time requirement for pharmacy staff, some services may require additional financial resources, either as a way to incentivize patients or obtain the equipment and resources needed. Providing financial incentives serves to motivate patients, and that expenditure may ultimately be recovered through additional patient spending in the store where the pharmacy is located, but it has not been demonstrated. ${ }^{28}$ Providing services with equipment, such as CPAP machines, can be expensive for pharmacies initially to obtain a stock of machines. ${ }^{35}$ However, initial information on the diagnosis of obstructive sleep apnea may be lacking and provide an opportunity for pharmacists to give patients more education, even without providing the CPAP machines. ${ }^{36}$

Pharmacists can play a significant role in reducing hospital readmissions, but it requires a well-established line of communication with physicians, which is often lacking in the community setting. ${ }^{42}$ Patients struggle to understand the role of medication counseling and find limited benefit for counseling on medication refills, which can limit the benefit pharmacists can provide to patients through repeated medication counseling. ${ }^{16}$ Conversely, pharmacists are effective at providing OTC counseling that leads to improved patient outcomes; however, patients may not want their physician to be made aware of their OTC use, and that can put the pharmacist in a difficult situation between the patient and the physician. ${ }^{4,24}$ Collaborative practice agreements can improve access for patients in rural areas, but care must be taken to select programs, which will benefit a significant number of patients. $^{40}$

Patients who participate in a screening that finds they have some level of risk are more inclined to pay for the screening service in an accessible location, such as a community pharmacy, and use of memory screenings in the pharmacy that are easy and quick to use can be extremely useful for patients. $^{38,39}$ Similarly, new services may have limited adoption in community settings when the time required for training is large or has limited flexibility, such as training that must be completed at a different location. ${ }^{34}$ Patients who experience a basic service are likely to be satisfied with the service, but patients who experience more specific or tailored service may have different perceptions of what constitutes quality pharmacy experiences and require more from their pharmacist to be satisfied with the encounter. ${ }^{9}$ Further, offering unique services may not be enough to draw new patients to a pharmacy, and pharmacists should work on developing strong relationships with patients in order to improve loyalty. ${ }^{7}$ A patient-centered approach can also improve retention of patients with chronic diseases. ${ }^{10}$ Patients may also benefit from better literacy-based communication techniques. ${ }^{33}$ Tailoring information and counseling to fit patient needs may improve the experience further. ${ }^{17,22}$

Improvements in laboratory measurements were are not always found to be related to improvements in quality of life, and that could also limit patient satisfaction. ${ }^{37}$ While patients who receive an intensive intervention may have more improvement, there has not been a demonstrated reduction in hospital admissions or doctor visits, limiting the impact to 
the overall health care costs. ${ }^{21}$ Similarly, the positive impacts were limited for patients receiving antidepressant counseling, and there was no statistically significant improvement in clinical symptoms, despite patients reporting a higher quality of life..$^{23}$ There was also only a modest improvement in medication costs when pharmacists provided medication reconciliation and counseling post hospital discharge, and no associated improvement in mortality, but patients may still report high satisfaction with the service. ${ }^{41}$ Those starting a selective serotonin reuptake inhibitor perceived a need for more tailored and actionable information regarding their medication use, and a lack of perceived empathy can limit the pharmacist-patient relationship. ${ }^{18}$ Mental health patients may also perceive a gap in care regarding how to stop a medication or the side effects or issues they experience as a result of taking a medication, and pharmacists are well placed to address that gap. ${ }^{19}$ Patients are not receiving focused education about their epilepsy from pharmacists but are open to pharmacists being involved in their care beyond medications. ${ }^{11}$

Conversely, when pharmacists are able to provide medications for minor ailments, patients experience improvement at a lower cost, but most of the ailments studied were generally self-limiting, so the pharmacist's impact may be overstated even though patients felt the pharmacist's interaction was beneficial. ${ }^{25,49}$ While pharmacists were effective at identifying medication-related problems in the primary care clinic, the interventions provided to improve adherence were patient education and counseling, which can be performed in the retail setting as well, perhaps with greater effect. ${ }^{20}$ Patients may need more information in order to establish adherence, and pharmacists must be aware of specific patient needs to appropriately provide that information. ${ }^{5}$ A patient-centered approach to medication management services can improve patient satisfaction, but it can result in increased costs to the health care system..$^{50,51}$ Maintaining a high level of professionalism and service is important for patient perceptions of pharmacy services, but as their exposure increases, their expectations and preferences increase as well, meaning that services may not be one-size-fits-all over an extended period of time. ${ }^{15}$ Patients have a low expectation for a pharmacist's ability to provide complementary medicine information, and it may be an area where pharmacists can improve patient satisfaction. ${ }^{14}$ Pharmacists can promote greater patient loyalty not only through professionalism but also through greater relational skills. ${ }^{8}$ In addition, patient groups, such as drug users, who experience a stigma from pharmacists are not as satisfied with their pharmacy services, but motivational interviewing may help overcome this stigma to improve patient perceptions of the pharmacist's interaction. ${ }^{32,52}$ Even without an intensive pharmacist's intervention, patients may experience satisfaction with pharmacy services just by talking with pharmacists about their medications and disease states. ${ }^{31}$ Few patients receive health promotion information from pharmacists, particularly in rural settings, and providing additional education for pharmacists could lead to a benefit for their patients. ${ }^{26}$ Pharmacies providing intramuscular contraception to patients generally provided injections to patients who were returning customers rather than new customers, indicating pharmacists may be better placed to maintain a patient base rather than expand, although pharmacies providing emergency contraception may gain new patients due to the ease of access compared to clinics. ${ }^{12,53}$

Community pharmacies are beginning to utilize technology in the provision of care, but it is still limited. As the society becomes more reliant upon technology, pharmacies may need to embrace the innovations and use them to greater advantage in order to improve pharmacy services and potentially increase patient satisfaction. Effective incorporation of technology can be as simple as using a phone call to follow up with patients to build patient rapport and identify problems, but requires pharmacy time and has not been shown to improve patient symptoms. ${ }^{47}$ Patients may feel that pharmacists are providing the services more for financial reasons rather than to improve patient care or be concerned about fragmented care when pharmacists provide more services, and that must be kept in mind when pharmacists consider new or changing services, particularly when technology is involved. ${ }^{48}$

\section{Conclusion}

As the role of pharmacists as health care providers expands, community pharmacies are providing more services to patients. While patients are generally satisfied with the services they receive from community pharmacists, their expectations are sometimes low and increase as patient exposure to advanced services increased. Pharmacists can have a greater impact on patient satisfaction through greater interpersonal skills than through the provision of new services; however, patients may be expanding their perceptions of how community pharmacists can be involved in their care beyond medication dispensing and counseling.

\section{Disclosure}

The authors report no conflicts of interest in this work. 


\section{References}

1. CMS.gov [webpage on the Internet]. Historical. Centers for Medicare and Medicaid. Available from: https://www.cms.gov/researchstatistics-data-and-systems/statistics-trends-and-reports/nationalhealthexpenddata/nationalhealthaccountshistorical.html. Accessed November 2, 2016.

2. BLS.gov [webpage on the Internet]. Occupational Outlook Handbook: Pharmacists. Bureau of Labor Statistics, U.S. Department of Labor. [updated December 17, 2015]. Available from: http://www.bls.gov/ooh/ healthcare/pharmacists.htm. Accessed November 2, 2016.

3. HHS.gov [webpage on the Internet]. Read the Law. U.S. Department of Health and Human Services. [updated August 28, 2015]. Available from: https://www.hhs.gov/healthcare/about-the-law/read-the-law/. Accessed November 2, 2016.

4. Simoens S, Lobeau M, Verbeke K, van Aerschot A. Patient experiences of over-the-counter medicine purchases in Flemish community pharmacies. Pharm World Sci. 2009;31(4):450-457.

5. Du Pasquier S, Aslani P. Concordance-based adherence support service delivery: consumer perspectives. Pharm World Sci. 2008;30(6):846-853.

6. Malewski DF, Ream A, Gaither CA. Patient satisfaction with community pharmacy: comparing urban and suburban chain-pharmacy populations. Res Social Adm Pharm. 2015;11(1):121-128.

7. Patterson BJ, Doucette WR, Urmie JM, McDonough RP. Exploring relationships among pharmacy service use, patronage motives, and patient satisfaction. J Am Pharm Assoc (2003). 2013;53(4):382-389.

8. Patricia Antunes L, Gomes JJ, Cavaco AM. How pharmacist-patient communication determines pharmacy loyalty? Modeling relevant factors. Res Social Adm Pharm. 2015;11(4):560-570.

9. Gastelurrutia MA, de San Vicente OG, Erauncetamurgil O, Odriozola I, Fernandez-Llimos F. Customers' expectations and satisfaction with a pharmacy not providing advanced cognitive services. Pharm World Sci. 2006;28(6):374-376.

10. McMillan SS, Sav A, Kelly F, King MA, Whitty JA, Wheeler AJ. How to attract them and keep them: the pharmacy attributes that matter to Australian residents with chronic conditions. Int J Pharm Pract. 2014;22(4): 238-245.

11. McAuley JW, Miller MA, Klatte E, Shneker BF. Patients with epilepsy's perception on community pharmacist's current and potential role in their care. Epilepsy Behav. 2009;14(1):141-145.

12. Akol A, Chin-Quee D, Wamala-Mucheri P, Namwebya JH, Mercer SJ, Stanback J. Getting closer to people: family planning provision by drug shops in Uganda. Glob Health Sci Pract. 2014;2(4):472-481.

13. Collum JL, Marcy TR, Stevens EL, Burns CF, Miller MJ. Exploring patient expectations for pharmacist-provided literacy-sensitive communication. Res Social Adm Pharm. 2013;9(5):626-632.

14. Tran S, Calabretto JP, Sorich M. Consumer-pharmacist interactions around complementary medicines: agreement between pharmacist and consumer expectations, satisfaction and pharmacist influence. Int J Pharm Pract. 2013;21(6):378-385.

15. Naik Panvelkar P, Armour C, Saini B. Community pharmacy-based asthma services - what do patients prefer? J Asthma. 2010;47(10): 1085-1093.

16. Kaae S, Traulsen JM, Norgaard LS. Customer interest in and experience with various types of pharmacy counselling - a qualitative study. Health Expect. 2014;17(6):852-862.

17. van Geffen EC, Philbert D, van Boheemen C, van Dijk L, Bos MB, Bouvy ML. Patients' satisfaction with information and experiences with counseling on cardiovascular medication received at the pharmacy. Patient Educ Couns. 2011;83(3):303-309.

18. van Geffen EC, Kruijtbosch M, Egberts AC, Heerdink ER, van Hulten R. Patients' perceptions of information received at the start of selective serotonin-reuptake inhibitor treatment: implications for community pharmacy. Ann Pharmacother. 2009;43(4):642-649.

19. Black E, Murphy AL, Gardner DM. Community pharmacist services for people with mental illnesses: preferences, satisfaction, and stigma. Psychiatr Serv. 2009;60(8):1123-1127.
20. Tan EC, Stewart K, Elliott RA, George J. Pharmacist consultations in general practice clinics: the Pharmacists in Practice Study (PIPS). Res Social Adm Pharm. 2014;10(4):623-632.

21. Kjeldsen LJ, Bjerrum L, Dam P, et al. Safe and effective use of medicines for patients with type 2 diabetes - a randomized controlled trial of two interventions delivered by local pharmacies. Res Social Adm Pharm. 2015; 11(1):47-62.

22. Hoffmann W, Herzog B, Muhlig S, et al. Pharmaceutical care for migraine and headache patients: a community-based, randomized intervention. Ann Pharmacother. 2008;42(12):1804-1813.

23. Rubio-Valera M, March Pujol M, Fernandez A, et al. Evaluation of a pharmacist intervention on patients initiating pharmacological treatment for depression: a randomized controlled superiority trial. Eur Neuropsychopharmacol. 2013;23(9):1057-1066.

24. Bosse N, Machado M, Mistry A. Efficacy of an over-the-counter intervention follow-up program in community pharmacies. J Am Pharm Assoc (2003). 2012;52(4):535-540.

25. Mansell K, Bootsman N, Kuntz A, Taylor J. Evaluating pharmacist prescribing for minor ailments. Int J Pharm Pract. 2015;23(2):95-101.

26. Sunderland B, Burrows S, Joyce A, McManus A, Maycock B. Rural pharmacy not delivering on its health promotion potential. Aust J Rural Health. 2006;14(3):116-119.

27. Mitchell B, Armour C, Lee M, et al. Diabetes Medication Assistance Service: the pharmacist's role in supporting patient self-management of type 2 diabetes (T2DM) in Australia. Patient Educ Couns. 2011;83(3): 288-294.

28. Hui-Callahan BC, Luder HR, Frede SM. Impact of the pay-forperformance-for-patients program for diabetes management. $\mathrm{J} \mathrm{Am}$ Pharm Assoc (2003). 2013;53(6):644-647.

29. American Pharmacists Association. DOTx. MED: pharmacist-delivered interventions to improve care for patients with diabetes. J Am Pharm Assoc (2003). 2012;52(1):25-33.

30. Saini B, LeMay K, Emmerton L, et al. Asthma disease managementAustralian pharmacists' interventions improve patients' asthma knowledge and this is sustained. Patient Educ Couns. 2011;83(3):295-302.

31. Saini B, Filipovska J, Bosnic-Anticevich S, Taylor S, Krass I, Armour C. An evaluation of a community pharmacy-based rural asthma management service. Aust J Rural Health. 2008;16(2):100-108.

32. Lea T, Sheridan J, Winstock A. Consumer satisfaction with opioid treatment services at community pharmacies in Australia. Pharm World Sci. 2008;30(6):940-946.

33. Warner JG, Portlock J, Smith J, Rutter P. Increasing seasonal influenza vaccination uptake using community pharmacies: experience from the Isle of Wight, England. Int J Pharm Pract. 2013;21(6):362-367.

34. O’Neal KS, Murray KA, Skomo ML, Carter SM, McConaha J. Validation of a survey tool assessing effectiveness of an educational intervention on the caring behaviors and referral activities of community pharmacists for migraineurs. Res Social Adm Pharm. 2015;11(3):352-363.

35. Hanes CA, Wong KK, Saini B. Clinical services for obstructive sleep apnea patients in pharmacies: the Australian experience. Int $J$ Clin Pharm. 2014;36(2):460-468.

36. Shoukry G, Wong K, Bartlett D, Saini B. Treatment experience of people with obstructive sleep apnoea seeking continuous positive airways pressure device provision through community pharmacies: a role for pharmacists? Int J Pharm Pract. 2011;19(5):318-327.

37. DiDonato KL, May JR, Lindsey CC. Impact of wellness coaching and monitoring services provided in a community pharmacy. J Am Pharm Assoc (2003). 2013;53(1):14-21.

38. Rickles NM, Skelton JB, Davis J, Hopson J. Cognitive memory screening and referral program in community pharmacies in the United States. Int J Clin Pharm. 2014;36(2):360-367.

39. Breslow RM. Patient attitudes regarding pharmacist-administered memory screening in community pharmacies. J Am Pharm Assoc (2003). 2013;53(6):648-651.

40. Jackson AN, Orr KK, Bratberg JP, Silverblatt F. Pharmacist initiation of postexposure doxycycline for Lyme disease prophylaxis. J Am Pharm Assoc (2003). 2014;54(1):69-73. 
41. Hugtenburg JG, Borgsteede SD, Beckeringh JJ. Medication review and patient counselling at discharge from the hospital by community pharmacists. Pharm World Sci. 2009;31(6):630-637.

42. Luder HR, Frede SM, Kirby JA, et al. TransitionRx: impact of community pharmacy postdischarge medication therapy management on hospital readmission rate. J Am Pharm Assoc (2003). 2015;55(3):246-254.

43. Butler KT, Ruisinger JF, Bates J, Prohaska ES, Melton BL. Participant satisfaction with a community-based medication synchronization program. J Am Pharm Assoc (2003). 2015;55(5):534-539.

44. Billups SJ, Delate T, Newlon C, Schwiesow S, Jahnke R, Nadrash A. Outcomes of a pharmacist-managed medication refill program. J Am Pharm Assoc (2003). 2013;53(5):505-512.

45. Stuurman-Bieze AG, Hiddink EG, van Boven JF, Vegter S. Proactive pharmaceutical care interventions decrease patients' nonadherence to osteoporosis medication. Osteoporos Int. 2014;25(6):1807-1812.

46. Stuurman-Bieze AG, Hiddink EG, van Boven JF, Vegter S. Proactive pharmaceutical care interventions improve patients' adherence to lipidlowering medication. Ann Pharmacother. 2013;47(11):1448-1456.

47. Beaucage K, Lachance-Demers H, Ngo TT, et al. Telephone follow-up of patients receiving antibiotic prescriptions from community pharmacies. Am J Health Syst Pharm. 2006;63(6):557-563.
48. Shaw J, Harrison J, Harrison J. A community pharmacist-led anticoagulation management service: attitudes towards a new collaborative model of care in New Zealand. Int J Pharm Pract. 2014;22(6):397-406.

49. Watson MC, Ferguson J, Barton GR, et al. A cohort study of influences, health outcomes and costs of patients' health-seeking behaviour for minor ailments from primary and emergency care settings. BMJ Open. 2015;5(2):e006261.

50. Tinelli M, Bond C, Blenkinsopp A, et al. Patient evaluation of a community pharmacy medications management service. Ann Pharmacother 2007;41(12):1962-1970.

51. Community Pharmacy Medicines Management Project Evaluation Team. The MEDMAN study: a randomized controlled trial of community pharmacy-led medicines management for patients with coronary heart disease. Fam Pract. 2007;24(2):189-200.

52. Jaffray M, Matheson C, Bond CM, et al. Does training in motivational interviewing for community pharmacists improve outcomes for methadone patients? A cluster randomised controlled trial. Int J Pharm Pract. 2014;22(1):4-12.

53. Black KI, Mercer CH, Kubba A, Wellings K. Provision of emergency contraception: a pilot study comparing access through pharmacies and clinical settings. Contraception. 2008;77(3):181-185.
Integrated Pharmacy Research and Practice

\section{Publish your work in this journal}

Integrated Pharmacy Research and Practice is an international, peer-reviewed, open access, online journal, publishing original research, reports, reviews and commentaries on all areas of academic and professional pharmacy practice. This journal aims to represent the academic output of pharmacists and pharmacy practice with particular focus on integrated care. All papers are carefully

\section{Dovepress}

peer reviewed to ensure the highest standards as well as ensuring that we are informing and stimulating pharmaceutical professionals. The manuscript management system is completely online and includes a very quick and fair peer-review system, which is all easy to use. Visit http://www.dovepress.com/ testimonials.php to read real quotes from published authors.

Submit your manuscript here: http://www.dovepress.com/integrated-pharmacy-research-and-practice-journal 